\title{
Article
}

\section{PI3-Kinase p110 $\alpha$ Deficiency Modulates T Cell Homeostasis and Function and Attenuates Experimental Allergic Encephalitis in Mature Mice}

\author{
José M. Rojo ${ }^{1, * \mathbb{D}}$, María Montes-Casado ${ }^{2} \mathbb{D}$, Laura Aragoneses-Fenoll ${ }^{2}$, Gloria Ojeda ${ }^{2}$, Umberto Dianzani $^{3}$ \\ and Pilar Portolés $2,4, * \mathbb{D}$ \\ 1 Departamento de Biomedicina Molecular, Centro de Investigaciones Biológicas Margarita Salas, CSIC, \\ 28040 Madrid, Spain \\ 2 Unidad de Inmunología Celular, Centro Nacional de Microbiología, Instituto de Salud Carlos III, \\ Majadahonda, 28220 Madrid, Spain; mmontes@isciii.es (M.M.-C.); laragoneses@isciii.es (L.A.-F.); \\ gojeda@isciii.es (G.O.) \\ 3 Interdisciplinary Research Center of Autoimmune Diseases (IRCAD), Department of Health Sciences, \\ University of Piemonte Orientale (UPO), 28100 Novara, Italy; umberto.dianzani@med.uniupo.it \\ 4 Presidencia, Consejo Superior de Investigaciones Científicas (CSIC), 28006 Madrid, Spain \\ * Correspondence: jmrojo@cib.csic.es (J.M.R.); pportols@isciii.es (P.P.)
}

check for

updates

Citation: Rojo, J.M.; Montes-Casado, M.; Aragoneses-Fenoll, L.; Ojeda, G.; Dianzani, U.; Portolés, P. PI3-Kinase p110 $\alpha$ Deficiency Modulates T Cell Homeostasis and Function and Attenuates Experimental Allergic Encephalitis in Mature Mice. Int. J. Mol. Sci. 2021, 22, 8698. https:// doi.org/10.3390/ijms22168698

Academic Editor: Maria Liguori

Received: 15 July 2021

Accepted: 11 August 2021

Published: 13 August 2021

Publisher's Note: MDPI stays neutral with regard to jurisdictional claims in published maps and institutional affiliations.

Copyright: (c) 2021 by the authors. Licensee MDPI, Basel, Switzerland. This article is an open access article distributed under the terms and conditions of the Creative Commons Attribution (CC BY) license (https:// creativecommons.org/licenses/by/ $4.0 /)$.

\begin{abstract}
Class I phosphoinositide 3-kinases (PI3K) are involved in the development of normal and autoimmune responses, including Experimental Autoimmune Encephalomyelitis (EAE), a mouse model for human multiple sclerosis (MS). Here, the role of the ubiquitously expressed class IA PI3K p110 $\alpha$ catalytic subunits in EAE has been analyzed using a model of Cre/flox mediated T cell specific deletion of $\mathrm{p} 110 \alpha$ catalytic chain $(\mathrm{p} 110 \alpha \Delta \mathrm{T})$. Comparison of two month-old (young) and six monthold (mature) p110 $\alpha \Delta \mathrm{T}$ mice and their wild type (WT) counterparts indicated loss of spleen CD4 ${ }^{+} \mathrm{T}$ cells that increased with age, indicating a role of $\mathrm{p} 110 \alpha$ in their homeostasis. In contrast, $\mathrm{CD}^{+} \mathrm{T}$ regulatory (Treg) cells were enhanced in mature p110 $\alpha \Delta$ T mice when compared to WT mice. Since Myelin Oligodendrocyte Glycoprotein (MOG) peptide-induced EAE is dependent on, or mediated by $\mathrm{CD}^{+} \mathrm{T}$ cells and $\mathrm{CD} 4^{+} \mathrm{T}$ cell-derived cytokines and controlled by Treg cells, development of EAE in young and mature WT or $\mathrm{p} 110 \alpha \Delta \mathrm{T}$ mice was analyzed. EAE clinical symptoms and disease scores in six month p110 $\alpha \Delta \mathrm{T}$ mice were significantly lower than those of mature WT, or young WT and p110 $\alpha \Delta$ T mice. Furthermore, ex vivo antigen activation of lymph node cells from MOG immunized mature $\mathrm{p} 110 \alpha \Delta \mathrm{T}$ mice induced significantly lower levels of IFN- $\gamma$ and IL-17A than young p $110 \alpha \Delta$ T or young and mature WT mice. Other cytokines including IL-2, IL-10 or TNF- $\alpha$ showed no significant differences between $\mathrm{p} 110 \alpha \Delta \mathrm{T}$ and WT mature mice. Our data show a lower incidence of MOG-induced EAE in mature $\mathrm{p} 110 \alpha \Delta \mathrm{T}$ mice linked to altered $\mathrm{T}$ cell homeostasis and lower secretion of inflammatory cytokines.
\end{abstract}

Keywords: phosphatidylinositol 3-kinases; CD4 ${ }^{+}$T-lymphocytes; CD4 ${ }^{+}$Treg; autoimmune experimental encephalomyelitis; multiple sclerosis

\section{Introduction}

Experimental autoimmune encephalomyelitis (EAE) is a mouse model for human multiple sclerosis (MS), an inflammatory, progressively disabling disease in which elements of the immune system attack and destroy the myelin sheath covering central nervous system neurons [1]. Specific agents causing MS have not described, although it is known that different environmental and genetic factors significantly increase the risk to develop the disease [1,2]. The participation of an array of different cellular and molecular innate and adaptive immune elements at different sites and times during MS requires the identification of effective therapeutic targets, particularly in primary and secondary progressive MS [2]. 
In this regard, animal models of MS, such as EAE, are essential in current efforts to analyze disease mechanisms and new therapeutic approaches [3].

The development of EAE-induced by administration of Myelin Oligodendrocyte Glycoprotein (MOG) is dependent on $\mathrm{CD}^{+} \mathrm{T}$ cells producing Th1 and Th17 cytokines such as IFN- $\gamma$, TNF- $\alpha$ and IL-17A [3-5]. The severity of the disease is negatively controlled by regulatory cells including regulatory $\mathrm{CD}^{+} \mathrm{T}$ cells (Treg) [6-8] and anti-inflammatory cytokines such as IL-10 [6,9-14].

Class I phosphoinositide 3-kinases (PI3K) signals are involved in the development of normal and autoimmune responses, including the differentiation, proliferation, homeostasis, metabolism, effector mechanisms, and migration of immune cells (reviewed in [15-23]). Class I PI3K form heterodimers composed of regulatory and catalytic subunits that phosphorylate dually phosphorylated phosphoinositides of cell membranes (PI $(4,5) \mathrm{P} 2)$ in the $3-\mathrm{OH}$ position of the inositol ring to generate $(\mathrm{PI}(3,4,5) \mathrm{P} 3$ (PIP3)). PI3Ks are activated by the recruitment of the regulatory subunits through membrane-proximal phosphorylated tyrosine motifs (in class IA PI3K) and G-protein receptor subunits (in class IB PI3K). Of interest to this work, Class IA PI3Ks participate in the differentiation of $\mathrm{CD}^{+} \mathrm{T}$ effector cells involved in EAE, including Th1/Th17 [24-33] and Treg cells [26,34-39].

The class IA regulatory subunits $\mathrm{p} 85 \alpha, \mathrm{p} 50 \alpha, \mathrm{p} 55 \alpha, \mathrm{p} 85 \beta$ and $\mathrm{p} 55 \gamma$ form dimers with $\mathrm{p} 110 \alpha, \mathrm{p} 110 \beta$ or $\mathrm{p} 110 \delta$ catalytic subunits. Whereas the catalytic subunits $\mathrm{p} 110 \alpha$ and $\mathrm{p} 110 \beta$ are ubiquitously expressed, the p1108 polypeptides are mainly expressed by hematopoietic cells $[15,22,40]$. Mouse CD4 $4^{+} \mathrm{T}$ lymphocytes and T cell lines express $\mathrm{p} 110 \alpha$ and $\mathrm{p} 110 \delta$, with $\mathrm{p} 110 \beta$ isoforms being marginally expressed [41]. Many lines of evidence show the importance of p1108 in T cell differentiation and function, including the use of specific inhibitors, or the data from $\mathrm{p} 110 \delta$-deficient mice or humans, and from mice expressing p1108 kinase-dead mutants [24-26,28-39].

Unlike p1108 deficiency, p110 $\alpha$ deficiency is lethal to embryo development [42], so the role of $\mathrm{p} 110 \alpha$ in $\mathrm{T}$ cells needs to be explored using subunit-specific inhibitors or Tcell specific deletion or inactivation. Our previous data using different pharmacological inhibitors specific for $\mathrm{p} 110 \alpha$ alone or in combination with $\mathrm{p} 110 \delta$ show a role for $\mathrm{p} 110 \alpha$ in different T- and B-dependent responses in vitro and in vivo, and the inhibition of EAE by a dual inhibitor of $\mathrm{p} 110 \alpha$ and DNA protein kinase [30,41,43]. Intriguingly, we have recently shown that T-cell-specific deletion of p $110 \alpha$ leads to enhanced activation of $\mathrm{CD} 4^{+}$and $\mathrm{CD} 8^{+}$ $\mathrm{T}$ cell in vitro, including enhanced Th1 and Th17 responses that might be relevant to EAE development [31]. These data, plus the diminished proportion of $\mathrm{CD}^{+} \mathrm{T}$ lymphocytes observed in the absence of $p 110 \alpha$ [31] and the role of p110 $\alpha$ in Treg function [39], prompted us to analyze the evolution of p $110 \alpha$-deficient $\mathrm{T}$ cells over time and its impact in the development of autoimmune encephalitis.

Here, we show that the loss of $\mathrm{CD}^{+} \mathrm{T}$ lymphocytes is maintained over time, but the proportion of Treg is enhanced in mice whose T cells lack $\mathrm{p} 110 \alpha$ (p110 $\alpha \Delta \mathrm{T}$ mice). Besides, unlike two month old mice, mature, six month old p110 $\alpha \Delta$ T mice develop a milder form of experimental encephalomyelitis. This suggests that subtle changes caused by p110 $\alpha$ PI3K in the survival and function of $\mathrm{T}$ cell subpopulations during adulthood have a profound impact on the development of EAE, confirming the potential therapeutic interest of PI3K isoforms in MS.

\section{Results}

2.1. Altered Cell Populations in Secondary Lymphoid Organs from Mice with PI3-K p110 $\alpha$-Deficient $T$ Cells

Our previous data indicated that the percentage of $\mathrm{CD} 4^{+} \mathrm{T}$ cells was significantly lower in the secondary lymphoid organs of young p $110 \alpha \Delta$ T mice [31]. To assess whether this process was dependent on aging and its impact in distinct functional $\mathrm{T}$ cell subpopulations, spleen cell populations were compared in two and six month old female mice (Figure 1). In agreement with our previous data, the percentage of $\mathrm{CD}^{+} \mathrm{T}$ cells was significantly lower in $\mathrm{p} 110 \alpha \Delta \mathrm{T}$ mice than their age-matched wild type (WT) counterparts (Figure 1a); aging lowered the percentage of $\mathrm{CD}^{+} \mathrm{T}$ cells in p110 $\alpha \Delta \mathrm{T}$ or WT mice (Figure 1a). The 
fraction of $\mathrm{CD} 4^{+} \mathrm{T}$ cells with a naïve phenotype $\left(\mathrm{CD} 62 \mathrm{~L}^{+} \mathrm{CD} 44^{\text {lo }}\right)$ was significantly lower in six month-old than in two month-old $\mathrm{p} 110 \alpha \Delta \mathrm{T}$ mice (Figure 1a). This indicates a role for the $\mathrm{p} 110 \alpha$ PI3-K subunit in the homeostasis of naïve $\mathrm{CD} 4^{+} \mathrm{T}$ cells. Besides, in agreement with published data, the proportion of $\mathrm{CD} 62 \mathrm{~L}^{\mathrm{lo}} \mathrm{CD} 44^{\text {hi }}$ effector/memory $\mathrm{CD} 4^{+} \mathrm{T}$ cells was enhanced in older mice; yet, no significant effect due to the mutant genotype was observed in same age mice (Figure 1a).

a)
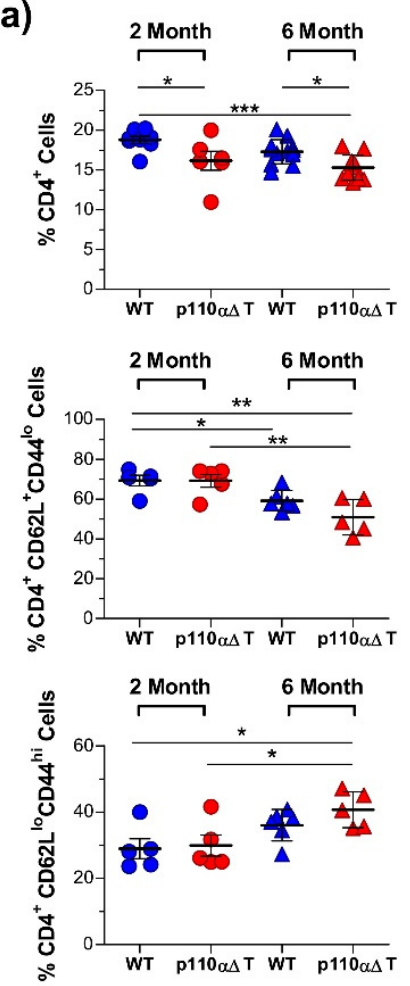

b)

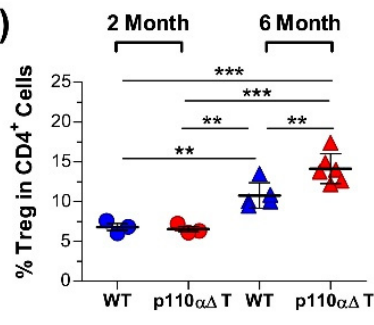

c)

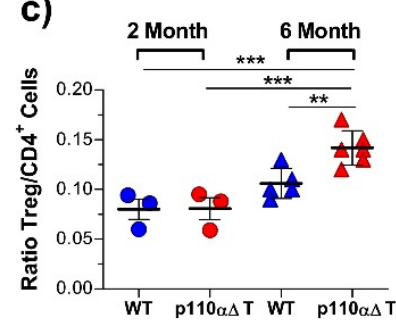

e)

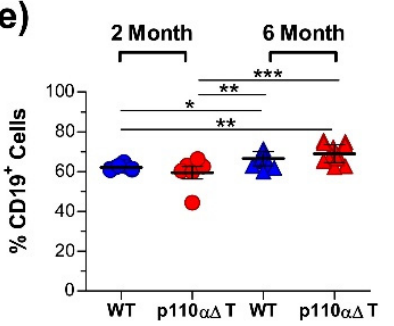

d)
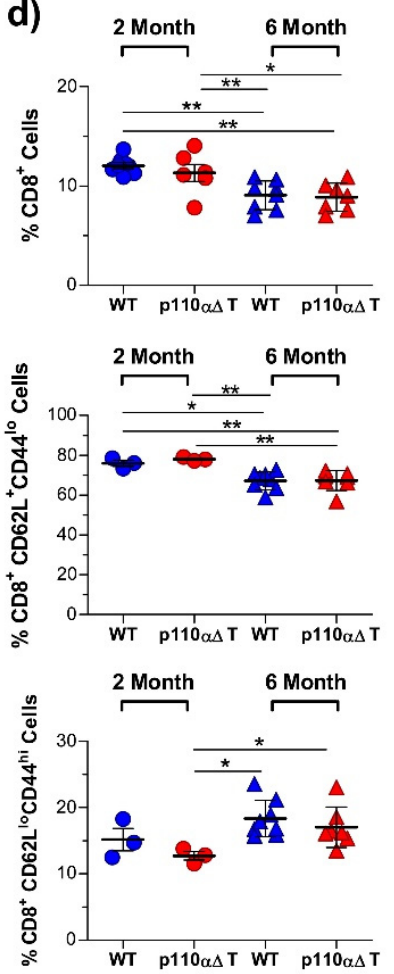

Figure 1. Flow cytometry analysis of spleen cell lymphocyte subpopulations in young, 2 month-old, or mature, 6 month-old wild type (WT) and p110 $\alpha \Delta \mathrm{T}$ mice. (a) Percentage of $\mathrm{CD} 4^{+} \mathrm{T}$ cells (top), naïve $\mathrm{CD} 4^{+} \mathrm{T}$ cells $\left(\mathrm{CD} 62 \mathrm{~L}^{+} \mathrm{CD} 44^{\mathrm{lo}}\right.$, middle), and effector/memory CD4 $4^{+} \mathrm{T}$ cells $\left(\mathrm{CD} 62 \mathrm{~L}^{\mathrm{lo}} \mathrm{CD} 44^{\mathrm{hi}}\right.$, bottom) in young (circles), or mature mice (triangles). (b) Percentage of regulatory T cells (Treg, $\mathrm{CD}_{2} 5^{+} \mathrm{Foxp}^{+}$in $\mathrm{CD}^{+} \mathrm{T}$ cells). (c) Ratio of Treg to conventional, non-Treg Foxp3 ${ }^{-} \mathrm{CD} 4^{+} \mathrm{T}$ cells. (d) Percentage of $\mathrm{CD}^{+} \mathrm{T}$ cells (top), naïve $\mathrm{CD} 8^{+} \mathrm{T}$ cells $\left(\mathrm{CD} 62 \mathrm{~L}^{+} \mathrm{CD} 44^{\mathrm{lo}}\right.$, middle), and effector/memory CD8 ${ }^{+} \mathrm{T}$ cells (CD62 ${ }^{\mathrm{lo}} \mathrm{CD} 44^{\text {hi }}$, bottom). (e) Percentage of $\mathrm{CD} 19^{+}$cells (B cells). Data from individual WT (blue symbols) or p110 $\alpha \Delta$ T mice (red symbols), as well as the mean \pm SEM for each group, are depicted. Only significant differences between groups are indicated, as determined by oneway ANOVA $\left.{ }^{*} p<0.05,{ }^{* *} p<0.01,{ }^{* * *} p<0.001\right)$. WT 2 month, $n=8$ ((a) top, (d) top, (e)); $n=5$ ((a) middle, (a) bottom); $n=3$ ((b), (c), (d) middle, (d) bottom). p110 $\alpha \Delta \mathrm{T} 2$ month, $n=6$ ((a) top, (d) top, (e)); $n=5$ ((a) middle, (a) bottom); $n=3$ (b), (c), (d) middle, (d) bottom). WT 6 month, $n=12$ (a) top, (e)); $n=8$ (d) top, (d) middle, (d) bottom), $n=6$ (a) middle, (a) bottom); $n=5$ (b), (c)). p110 $\alpha \Delta \mathrm{T} 6$ month, $n=11$ (a) top, (e)); $n=7$ (d) top, (d) middle, (d) bottom), $n=6$ (b), (c)); $n=5$ (a) middle, (a) bottom).

Figure $1 \mathrm{~b}, \mathrm{c}$ show that $\mathrm{CD} 4^{+}$Treg cells $\mathrm{CD} 4^{+}$were clearly higher in older mice, considering either the percentage of Treg cells in $\mathrm{CD} 4^{+} \mathrm{T}$ lymphocytes or the ratio of Treg to $\mathrm{CD} 4^{+}$ $T$ cells. Besides, the proportion of Treg cells was significantly enhanced in six month-old p $110 \alpha \Delta \mathrm{T}$ mice as compared to WT mice (Figure $1 \mathrm{~b}, \mathrm{c}$ ). This might reflect the importance of the PI3-K p1108 subunit in Treg numbers and function [34,39], as p1108 is the main PI3-K subunit remaining in p110 $\alpha$-deficient T cells [31,41]. 
The analysis of whole $\mathrm{CD} 8^{+} \mathrm{T}$ cells or the naïve $\left(\mathrm{CD} 62 \mathrm{~L}^{+} \mathrm{CD} 44^{\mathrm{lo}}\right) \mathrm{CD} 8^{+}$population shows a significantly lower proportion in older mice but no significant differences between cells of $\mathrm{p} 110 \alpha \Delta \mathrm{T}$ and WT mice of the same age (Figure 1d, top and middle panels). In the same way as $\mathrm{CD} 4^{+} \mathrm{T}$ cells, CD62 $\mathrm{L}^{\text {lo }} \mathrm{CD} 44^{\text {hi }}$ effector/memory $\mathrm{CD} 8^{+} \mathrm{T}$ cells were enhanced in older mice, and no significant effect was observed between cells with or without $\mathrm{p} 110 \alpha$ PI3-K from mice of the same age (Figure 1d, lower panel). The loss of T cells in older mice was compensated by an enhanced proportion of B cells $\left(\mathrm{CD} 19^{+}\right.$cells (Figure 1e)) which was higher in $\mathrm{p} 110 \alpha \Delta \mathrm{T}$ mice.

\subsection{Development of Experimental Allergic Encephalitis in Young and Mature p110 $\Delta T$ T Mice}

One hallmark of naïve CD4 $4^{+} \mathrm{T}$ cells from $\mathrm{p} 110 \alpha \Delta \mathrm{T}$ mice is the enhanced secretion of certain cytokines such as IFN- $\gamma$ when activated by anti-CD3 plus anti-CD28 antibodies [31]. This feature was maintained in cells from 6 month old mice, as shown in Figure S1. Besides, $\mathrm{p} 110 \alpha \Delta \mathrm{T} \mathrm{CD} 4^{+} \mathrm{Th} 1, \mathrm{Th} 17$, or Tfh cells in vitro, or $\mathrm{p} 110 \alpha \Delta \mathrm{T}$ mice in vivo showed enhanced cytokine production including IL-17A, IFN- $\gamma$, or TNF- $\alpha$ [31].

Taking these data into account, plus the changes in naïve and Treg $\mathrm{CD} 4^{+} \mathrm{T}$ cells observed in $\mathrm{p} 110 \alpha \Delta \mathrm{T}$ mature mice, we analyzed the role of T cell $\mathrm{p} 110 \alpha$ deletion in MOGinduced EAE by comparing the response in young ( 2 month old) and mature (6 month old) WT or p $110 \alpha \Delta \mathrm{T}$ mice. EAE was chosen as a model where: (a) development is dependent or mediated by effector $\mathrm{CD} 4^{+} \mathrm{T}$ cells and cytokines such as IL-17A, IFN- $\gamma$, TNF- $\alpha$ (reviewed in $[4,5])$; (b) Treg cells control the outcome of the disease [6,7]; (c) mature mice develop similar or stronger disease than young mice [44-46].

Strikingly, EAE symptoms and disease scores in six month p $110 \alpha \Delta$ T mice were clearly lower than those of mature WT, or young WT and p $110 \alpha \Delta$ T mice (Figure 2). Significant differences between mature $\mathrm{p} 110 \alpha \Delta \mathrm{T}$ mice and all other experimental groups were observed in daily clinical scores, (Figure 2a). Furthermore, whereas no deaths were observed among the 6 month old p110 $\alpha \Delta$ T mice, deaths occurred in all other groups, with significant survival differences between mature WT and $\mathrm{p} 110 \alpha \Delta \mathrm{T}$ mice (Figure $2 \mathrm{a}, \mathrm{b}$ ). Significant differences between mature $\mathrm{p} 110 \alpha \Delta \mathrm{T}$ mice and the other experimental groups were also observed concerning the areas under the curve (Figure 2c), the disease index (Figure 2d) and the maximal disease score (Figure 2e). The days of disease onset in the different groups $(13.50 \pm 0.73$ (young WT), $13.71 \pm 0.74$ (young p110 $\alpha \Delta \mathrm{T}$ ) $13.63 \pm 0.75$ (mature WT), and $15.80 \pm 1.20$ (mature $\mathrm{p} 110 \alpha \Delta \mathrm{T}$ )) were not significantly different.

Significant differences in the lymphoid populations from draining the lymph nodes of immunized mice at day 28 after EAE induction were mainly related to aging, particularly an enhanced percentage of Treg cells, enhanced Treg to Tconv ratios, or lower percentage of B lymphocytes (Figure S2). Yet, mature p110 $\alpha \Delta \mathrm{T}$ mice had a significantly lower proportion of $\mathrm{CD}^{+} \mathrm{T}$ lymphocytes than mature WT mice (Figure S2).

\subsection{Cytokine Production by Lymph Node Cells from Young and Mature MOG-Immunized Mice}

At 28 days of EAE induction, cells from the draining lymph nodes of the surviving mice were activated with the MOG antigen peptide, and cytokines in the supernatants were determined (Figure 3). Cells from young $\mathrm{p} 110 \alpha \Delta \mathrm{T}$ mice produced significantly higher levels of IFN- $\gamma$ than cells from young WT mice (Figure 3a). The levels of IL-17A and TNF- $\alpha$ were also higher in young p $110 \alpha \Delta \mathrm{T}$ mice, although differences with young WT mice were not significant (Figure 3b,d). IL-10 levels were similar in both groups of young mice (Figure 3c). There were two major differences between young and mature WT mice concerning MOG-specific response, namely a drop in IFN- $\gamma$ production and an enhanced IL-10 production by cells from older animals (Figure 3a,c). No significant differences were observed concerning IL-17A and TNF- $\alpha$ secretion between young and mature WT mice (Figure 3b,d). 
a)

2 Month Old

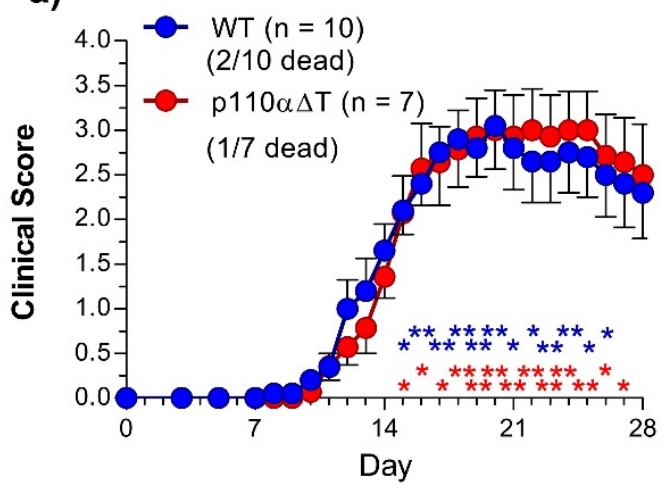

b)

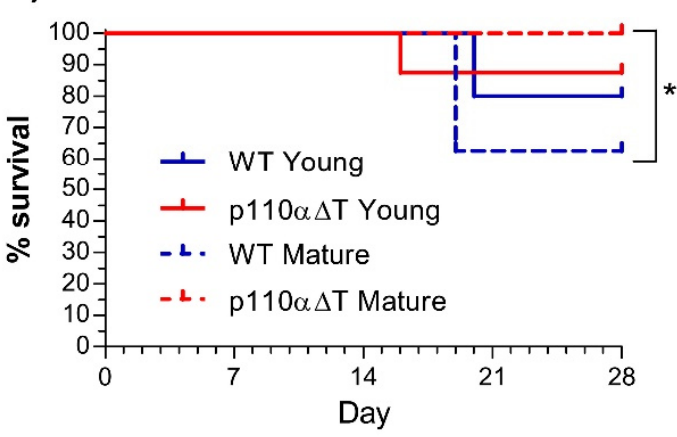

d)

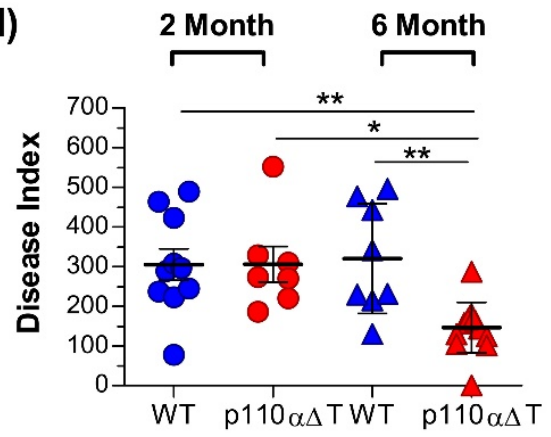

6 Month Old

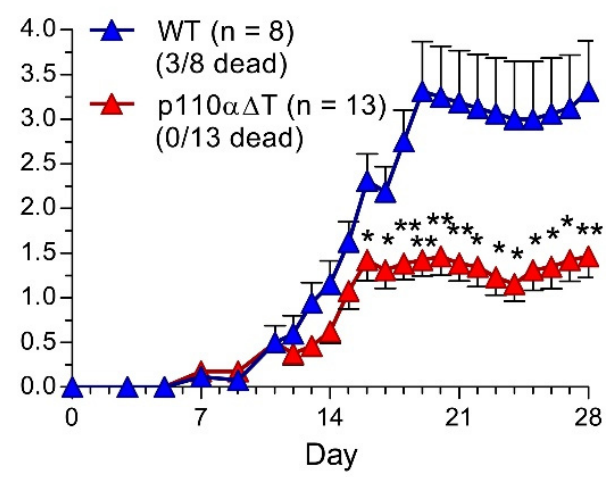

c)

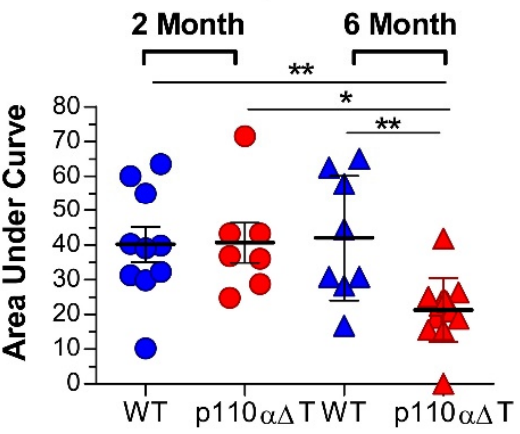

e)

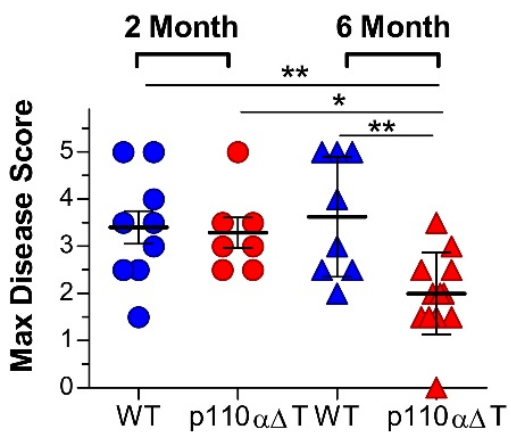

Figure 2. Comparison of Experimental Allergic Encephalomyelitis (EAE) disease parameters in young or mature wild type (WT) and $\mathrm{p} 110 \alpha \Delta \mathrm{T}$ mice, (a) Daily average Disease Score; (b) Percent Survival; (c) Area Under the Curve; (d) Disease Index; (e) Maximum Disease Score. In (a), the mean \pm SEM of daily disease scores for each group is represented; deaths and the number of mice in each group are given in parentheses. The left graph in (a) shows data from young WT (blue circles) or $\mathrm{p} 110 \alpha \Delta \mathrm{T}$ mice (red circles); the right graph shows data from mature WT (blue triangles) or $\mathrm{p} 110 \alpha \Delta \mathrm{T}$ mice (red triangles). (b) Survival of young (solid lines) or mature (dotted lines) WT (blue lines), or p110 $\alpha \Delta \mathrm{T}$ mice (red lines) is shown. In (c-e), the data from individual young (circles) or mature (triangles) WT (blue symbols) or p110 $\alpha \Delta \mathrm{T}$ mice (red symbols), as well as the mean \pm SEM for each group, are depicted. Data from two different experiments each of young and mature mice; individual data from young WT ( $n=10$, blue circles), young p110 $\alpha \Delta \mathrm{T}$ ( $n=7$, red circles), mature WT ( $n=5$, blue triangles), and mature $\mathrm{p} 110 \alpha \Delta \mathrm{T}$ mice ( $n=8$, red triangles) are shown. Only significant differences between groups are indicated, as determined by One-way ANOVA (a,c-e; $\left.{ }^{*} p<0.05,{ }^{* *} p<0.01\right)$ or the log rank (Mantel-Cox) test $\left(\mathbf{b} ;{ }^{*} p<0.05\right)$. In (a), asterisks in blue indicate significant differences between young WT and mature $\mathrm{p} 110 \alpha \Delta \mathrm{T}$ mice; red asterisks indicate significant differences between young and mature $\mathrm{p} 110 \alpha \Delta \mathrm{T}$ mice; black asterisks indicate significant differences between mature WT and p110 $\alpha \Delta \mathrm{T}$ mice. 
a)

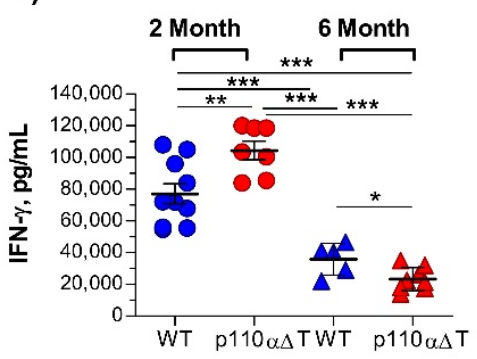

c)

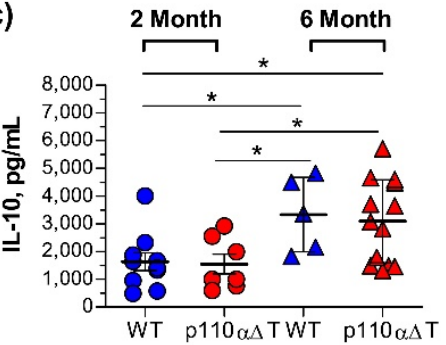

b)

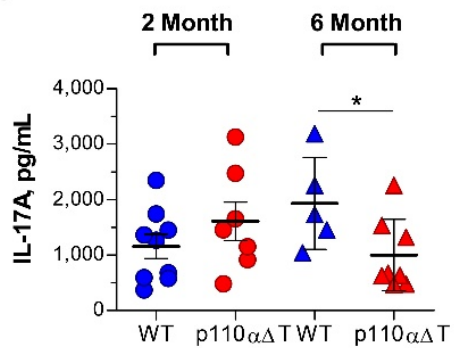

d)

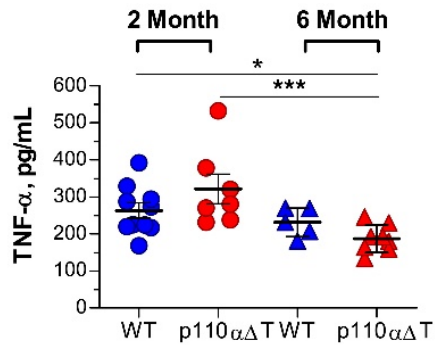

e)
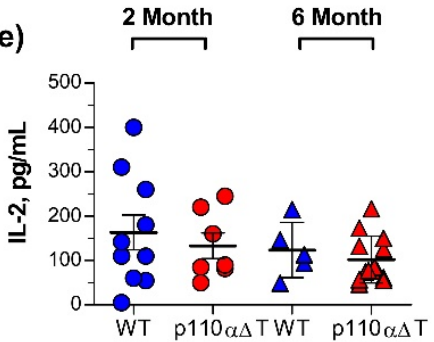

Figure 3. Cytokine secretion by lymph node cells from young and mature wild type (WT) or p110 $\alpha \Delta \mathrm{T}$ mice undergoing Experimental Allergic Encephalomyelitis (EAE). Lymph node cells from individual mice surviving on day 28 after Myelin Oligodendrocyte Glycoprotein (MOG) immunization were cultured for $96 \mathrm{~h}$ in the presence of MOG peptide antigen. Then, cytokine content in the supernatants was determined, as follows: (a) IFN- $\gamma$; (b) IL-17A; (c) IL-10; (d) TNF- $\alpha$; (e) IL-2. Data from two different experiments each of young and mature mice; individual data from young WT $(n=10$, blue circles), young p $110 \alpha \Delta \mathrm{T}$ ( $n=7$, red circles), mature WT ( $n=5$, blue triangles), and mature $\mathrm{p} 110 \alpha \Delta \mathrm{T}$ mice $(n=8$, red triangles) are shown. Significant differences between groups are indicated, as determined by One-way ANOVA $\left({ }^{*} p<0.05,{ }^{* *} p<0.01,{ }^{* * *} p<0.001\right)$.

Interestingly, unlike young p110 $\alpha \Delta \mathrm{T}$ mice, cells from mature $\mathrm{p} 110 \alpha \Delta \mathrm{T}$ mice undergoing EAE secreted significantly lower levels of IFN- $\gamma$ than WT mice (Figure 3a). Furthermore, the levels of the inflammatory cytokine IL-17A were significantly lower in mature p $110 \alpha \Delta \mathrm{T}$ than in WT mice, and TNF- $\alpha$ was lower in mature $p 110 \alpha \Delta \mathrm{T}$ mice when compared to either 2 month-old p $110 \alpha \Delta \mathrm{T}$ or WT mice (Figure 3b,d). IL-10 was enhanced in mature mice, but there were no differences between p $110 \alpha \Delta \mathrm{T}$ and WT of the same age. No significant differences were observed in IL-2 levels. These data, plus the significant correlation between clinical score and IL-17A, IFN- $\gamma$, but not IL-2 or IL-10 secretion (Figure S3), suggest that the lower incidence of EAE in p $110 \alpha \Delta \mathrm{T}$ mature mice is primarily due to their lower secretion of the IL-17A and IFN- $\gamma$ inflammatory cytokines. Intriguingly, at the time considered there was an inverse correlation between TNF- $\alpha$ secretion and the EAE clinical score (Figure S3).

Whether some of the effects observed in mature $\mathrm{p} 110 \alpha \Delta \mathrm{T}$ mice were due to altered aging and/or exhaustion of conventional $\mathrm{CD}^{+} \mathrm{T}$ cells, or to the development and function of Treg cells was analyzed. So, the expression of markers linked to aging, exhaustion, and Treg function was determined. These included PD-1, ICOS, CXCR5, and Eomesodermin (Eomes) [47-54]. No significant differences between mature WT and $\mathrm{p} 110 \alpha \Delta \mathrm{T}$ mice were observed concerning PD-1, ICOS, CXCR5, or Eomes expression in CD4 ${ }^{+}$T lymphocytes, 
although there was a slight reduction of PD- $1^{+}$cells expressing ICOS (Figure S4a). Among Treg cells there were no significant differences in PD-1 expression; a minor reduction of $\mathrm{ICOS}^{+}$or PD- $1^{+} \mathrm{ICOS}^{+}$Treg cells was appreciated (Figure S4b).

\subsection{Early Anti-MOG Responses in Mature $p 110 \alpha \Delta T$ Mice}

To determine possible differences during EAE induction, the antigen-specific cytokine response was analyzed at an earlier time (day 14) where EAE symptoms could be detected, yet clinical scores between WT and $\mathrm{p} 110 \alpha \Delta \mathrm{T}$ mice were not significantly different (Figure 4a), and draining lymph node populations were similar (Figure S5). Cells from the draining lymph nodes were activated with antigen in vitro and cytokines in the supernatants determined. The data in Figure 4 show significant differences between $\mathrm{p} 110 \alpha \Delta \mathrm{T}$ and WT mice in IL-17A and IFN- $\gamma$ contents, but not in secreted IL-2 or IL-10 (Figure $4 \mathrm{~b}-\mathrm{e}$ ). Differences between $\mathrm{p} 110 \alpha \Delta \mathrm{T}$ and WT mice in TNF- $\alpha$ concentration were not significant (Figure 4f), although there was a significantly positive correlation between TNF- $\alpha$ secretion and EAE score at 14 days (Figure S6c).; significant correlations with EAE score were also found for IL-17A and IFN- $\gamma$ (Figure S6a,b).

a)

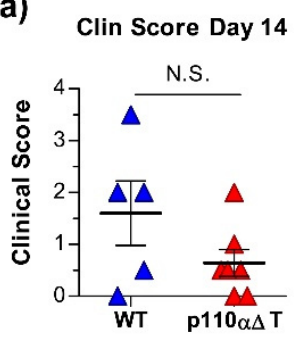

b)

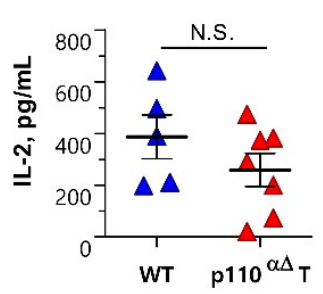

e)

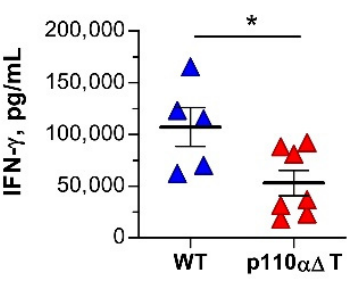

c)

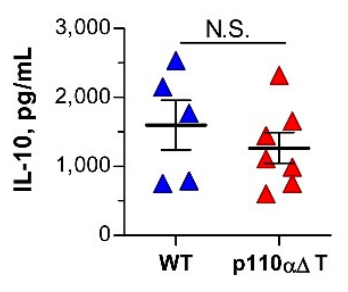

d)

IL-17A, Day 14

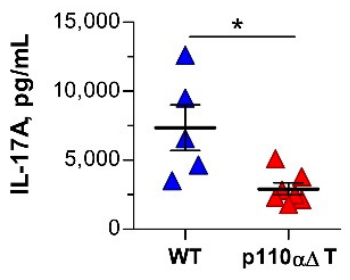

Figure 4. Secretion of cytokines by lymph node cells from individual mature wild type (WT) or p $110 \alpha \Delta$ T mice obtained after 14 days of Experimental Allergic Encephalomyelitis (EAE) induction with Myelin Oligodendrocyte Glycoprotein (MOG) peptide. Cells were cultured for $96 \mathrm{~h}$ in the presence of MOG peptide antigen, and cytokine content in the supernatants was determined. (a) clinical EAE score; (b) IL-2; (c) IL-10; (d) IL-17A; (e) IFN- $\gamma$; (f) TNF- $\alpha$. Data from mature WT $(n=5)$, and $\mathrm{p} 110 \alpha \Delta \mathrm{T}(n=7)$ mice are shown. Significant differences between groups are indicated, as determined with the Mann-Whitney $U$ test (a), or the unpaired two-tailed Student ${ }^{\prime} t$ test $(\mathbf{b}-\mathbf{f})$. * $p<0.05$; N.S.: not significant.

\section{Discussion}

We show here that mice whose T cells lack the PI3-K p110 $\alpha$ subunit have a marked age-related difference concerning their susceptibility to EAE. Whereas the development of EAE symptoms in young p $110 \alpha \Delta \mathrm{T}$ mice is similar to that of WT mice, EAE is significantly milder in mature p110 $\alpha \Delta$ T mice than in WT age-matched mice, or than in young WT and $\mathrm{p} 110 \alpha \Delta \mathrm{T}$ mice. A number of differences observed between mature WT and $\mathrm{p} 110 \alpha \Delta \mathrm{T}$ mice might contribute to the low susceptibility. First, the population of $\mathrm{CD}^{+} \mathrm{T}$ lymphocytes that is primarily involved in EAE development was significantly diminished in mature $\mathrm{p} 110 \alpha \Delta \mathrm{T}$ mice, yet the subpopulation of $\mathrm{CD} 4^{+}$Treg cells was clearly enhanced. Secondly, secretion of IL-17A and IFN- $\gamma$ was significantly lower in cells from mature $\mathrm{p} 110 \alpha \Delta \mathrm{T}$ mice. 
Since there is abundant literature showing the relevance of Treg cells, IL-17A and IFN- $\gamma$ in the development and control of EAE [3-8,28], we suggest that differences in these factors are responsible for the distinct clinical outcome in mature $\mathrm{p} 110 \alpha \Delta \mathrm{T}$ mice.

First, we observed an enhanced proportion of Treg cells in mature WT mice that is further enhanced in mature $\mathrm{p} 110 \alpha \Delta \mathrm{T}$ mice. An enhanced proportion of Treg is likely contributing to EAE attenuation, and could be mediated by the activity of p1108 PI3-K, which is the main class IA PI3-K in CD4 ${ }^{+} \mathrm{T}$ cells remaining in the absence of p110 $\alpha$ [31], and essential to Treg differentiation and function in mice and humans [26,34-39]. In contrast, Treg-specific deletion of $\mathrm{p} 110 \alpha$ did not alter Treg proportions or function in the steady state, although it induced a slight reduction in EAE symptoms [39]. Indeed, we found no differences in Treg cells of young $\mathrm{p} 110 \alpha \Delta \mathrm{T}$ mice, whereas significant differences were observed in older animals. Recently, the attenuation of EAE in mice with PD-1-deficient Tregs has been linked to reduced PI3K-AKT signaling and the enhanced suppressive capacity of Treg cells [54]. However, we find no significant differences in PD-1 expression between Treg cells from mature WT and $\mathrm{p} 110 \alpha \Delta \mathrm{T}$ mice. Other recent data indicate that the loss of ICOS-mediated PI3K signaling is a key factor in enhancing Treg function [55]. In this regard, we and others have found lower ICOS PI3K signaling in p110 $\alpha$-deficient $\mathrm{CD}^{+} \mathrm{T}$ cells [41,56] or Treg cells [54]. This adds to the significantly lower expression of ICOS by the Treg cells from mature $\mathrm{p} 110 \alpha \Delta \mathrm{T}$ mice (Figure S4); all these factors together could contribute to enhanced Treg function in mature p110 $\alpha \Delta \mathrm{T}$ mice.

Surprisingly, p110 $\alpha \Delta \mathrm{T}$ mice have a lower percentage of $\mathrm{CD}^{+} \mathrm{T}$ cells [31], and our results show that this difference is maintained and enhanced in mature mice. A likely hypothesis is that the PI3-K p110 $\alpha$ isoform is involved in the signaling needed for the survival of $\mathrm{CD}^{+} \mathrm{T}$ cells, as has been observed in B lymphocytes $[57,58]$. The loss of $\mathrm{CD} 4^{+}$ $\mathrm{T}$ cells seems restricted to conventional, non-Treg $\mathrm{CD} 4^{+} \mathrm{T}$ cells, and might contribute to the lower incidence of EAE in mature p $110 \alpha \Delta \mathrm{T}$ mice. However, additional factors are needed, as EAE develops normally in young $\mathrm{p} 110 \alpha \Delta \mathrm{T}$ mice that also have a lower proportion of $\mathrm{CD}^{+} \mathrm{T}$ cells, and yet cells from these young mice produce higher amounts of IFN- $\gamma$ and IL-17A when challenged in vitro, in agreement with our previous data [31].

Th1- and Th17-derived cytokines participate in the development of EAE and MS. Our data confirm their importance in the development of EAE, and in the differences between mature WT and $\mathrm{p} 110 \alpha \Delta \mathrm{T}$ mice. Thus, we found significant correlations between MOG-dependent secretion of IFN- $\gamma$ and IL-17A and the EAE clinical score of mature mice. Furthermore, EAE attenuation in mature $\mathrm{p} 110 \alpha \Delta \mathrm{T}$ mice runs in parallel with significant reductions of both IFN- $\gamma$ and IL-17A. The reductions were specific for these cytokines and the $\mathrm{p} 110 \alpha \Delta \mathrm{T}$ phenotype, and in the case of IFN- $\gamma$, took place in the context of a strong age-linked reduction of cytokine production. In addition, lower IFN- $\gamma$ in mature p $110 \alpha \Delta \mathrm{T}$ mice was in contrast with the enhanced secretion in young mice, which was also found in isolated naïve $\mathrm{CD} 4^{+} \mathrm{T}$ cells from mature mice.

IL-10 secretion was also determined, as an anti-inflammatory cytokine that negatively controls EAE [6,9-14]. Antigen-dependent secretion of IL-10 was enhanced in mature as compared to young mice in the course of EAE, yet it was not different in WT or p $110 \alpha \Delta \mathrm{T}$ mice of the same age.

Th1 and Th17 cells are susceptible to Fas/FasL-induced cell death and IL-10-mediated suppression, respectively (reviewed in [5]). There is a possibility that in mature p110 $\alpha \Delta \mathrm{T}$ mice, Th1 cells express higher levels of Fas, or that Treg express enhanced levels of FasL, or both, so that Th1 responses are diminished. Similarly, the levels of IL-10R $\alpha$ in Th17 and/or Treg cells from mature p110 $\alpha \Delta \mathrm{T}$ mice might be enhanced, rendering Th17 cells more susceptible to inhibition [59] and Treg more efficient at suppressing Th17 [60]; all these factors need to be addressed further.

Taken together, our data indicate that deletion of $\mathrm{p} 110 \alpha$ in T cells induces the loss of certain $\mathrm{CD} 4^{+} \mathrm{T}$ cell subpopulations and favors the survival of Treg cells. Furthermore, in the absence of p $110 \alpha$ there is enhanced production of important effector cytokines by activated or differentiated naïve cells (this manuscript, and [31]). Thus, in young WT 
mice the presence of $\mathrm{p} 110 \alpha$ might tone down $\mathrm{T}$ cell responses, whereas the responses in mature WT animals might be favored by the improved survival of naïve T cells and a reduced population of Treg cells. Taking this into account, $\mathrm{p} 110 \alpha$ inhibitors could be tested as a therapeutic mode of restraining excess responses in autoimmune diseases without compromising the development of antipathogen or anticancer adaptive responses.

\section{Materials and Methods}

\subsection{Mice}

C57BL/6J mice (WT), CD4-Cre (strain B6;D2-Tg(Cd4-cre) 1Cwi/CwiCnrm, [61]), and

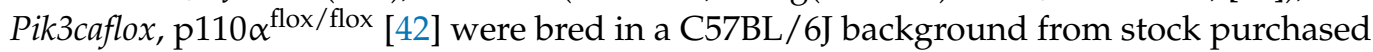
from Charles River or the European Mouse Mutant Archive (EMMA, CD4-Cre) at the animal care facilities of the Centro de Investigaciones Biológicas Margaritas Salas (CSIC, Madrid, Spain), or the Instituto de Salud Carlos III (Majadahonda, Madrid, Spain) under specific pathogen free conditions. Mice referred to as young, two month old, or mature, six month old, were 8-10 weeks old or 24-28 weeks old, respectively, at the start of the procedures. Female mice with T cells deficient for PI3K p110 $\alpha$ subunits $\left(\mathrm{CD} 4-\mathrm{Cre}^{+/-}\right.$ p $110 \alpha^{\text {flox/flox }} ; \mathrm{p} 110 \alpha \Delta \mathrm{T}$ ) and their $\mathrm{Cre}^{-/-}$littermates $\left(\mathrm{CD} 4-\mathrm{Cre}{ }^{-/-} \mathrm{p} 110 \alpha^{\text {flox/flox; WT) }}\right.$ were used. The experimental procedures were approved by the Ethics and Animal Welfare Committees of CSIC and Instituto de Salud Carlos III and were conducted according to institutional, national and European Union guidelines under project licenses PROEX 181/15 (to J.M.R., CSIC) and PROEX 330/15 (to P.P., ISCIII) issued by the Consejería de Medio Ambiente y Ordenación del Territorio, C.A. Madrid, Spain.

\subsection{EAE Induction and Measurement}

To induce EAE, mice were injected with $300 \mu \mathrm{g}$ of a rat Myelin Oligodendrocyte Glycoprotein peptide $\left(\mathrm{MOG}_{35-55}\right)$ in saline emulsified in CFA containing $500 \mu \mathrm{g}$ of heatkilled Mycobacterium tuberculosis. The emulsion was administered s.c. at two sites in the upper and lower back $(0.1 \mathrm{~mL} / \mathrm{site})$. Then, $0.5 \mu \mathrm{g}$ of pertussis toxin (Calbiochem, Merck Life Science S.L.U. Madrid, Spain) dissolved in $0.1 \mathrm{~mL}$ of PBS were injected i.p. $2 \mathrm{~h}$ and $48 \mathrm{~h}$ after MOG administration. Mice were periodically analyzed for clinical symptoms of EAE that were graded with the following Disease Scores: (0) no clinical signs; (1) loss of tail tone; (2) wobbly gait; (3) hind limb paralysis; (4) hind and fore limb paralysis; (5) death -0.5 gradations were given to intermediate scores. The disease parameters used have been defined in detail previously $[14,43,62]$. These included daily average Disease Score in each experimental group; Day of Disease Onset (mean of the first day with clinical symptoms of mice in one experimental group); Maximum Disease Score (mean of the highest Disease Score in each of the mice of one experimental group), and Disease Index (daily disease scores in each of the mice were added, then divided by the average day of disease onset of the group multiplied by 100; the values were averaged for each group). The Area Under the Curve (AUC) was determined for the daily Disease Scores of each individual mouse with GraphPad Prism software v. 9.0.0 (GraphPad Software, San Diego, CA, USA); then, the individual values were averaged for each experimental group.

\subsection{Antigen Activation Ex Vivo}

At the completion of the EAE experiments, the draining axillar and inguinal lymph nodes from MOG-injected mice were excised, and single cell suspensions were obtained from individual mice. Then, the cells $\left(1 \mathrm{~mL}\right.$ at $10^{6}$ cells $/ \mathrm{mL}$ in round-bottom tubes) were cultured for $96 \mathrm{~h}$ in Click's medium supplemented with $10 \%$ heat-inactivated fetal bovine serum and $50 \mu \mathrm{g} / \mathrm{mL}$ gentamicin (culture medium) in the presence of $100 \mu \mathrm{g} / \mathrm{mL}$ antigen MOG peptide [43]. Culture supernatants were eventually taken to determine cytokine content. 


\section{4. $\mathrm{CD} 4^{+} \mathrm{T}$ Cell Isolation and Activation}

Whole $\mathrm{CD} 4^{+} \mathrm{T}$ lymphocytes and naive $\mathrm{CD} 4^{+} \mathrm{T}$ were isolated from mouse spleen cell suspensions with the $\mathrm{CD} 4^{+} \mathrm{CD} 62 \mathrm{~L}^{+} \mathrm{T}$ cell isolation kit II (Miltenyi Biotec, Bergisch Gladbach, Germany). Whole $\mathrm{CD} 4^{+} \mathrm{T}$ lymphocytes obtained using this kit were devoid of $\mathrm{CD}^{+} \mathrm{CD} 25^{+}$(Treg) T cells. Cells in culture medium $\left(10^{6} / \mathrm{mL} ; 1 \mathrm{~mL} /\right.$ well) were activated in 24-well plates (Costar) pre-coated with anti-CD3 (YCD3-1, $5 \mu \mathrm{g} / \mathrm{mL}$ ) in the presence of anti-CD28 antibodies $(2.5 \mu \mathrm{g} / \mathrm{mL})$, as described in detail in [31]. The supernatants were collected after $48 \mathrm{~h}$ of culture and the cytokines analyzed.

\subsection{Cytokine Determination}

Cytokines in culture supernatants (IL-2, IL-10, IL-17A, IFN- $\gamma$, and TNF- $\alpha$ ) were quantified by capture ELISA using specific Ready-SET-Go! kits (eBioscience; San Diego, CA, USA) performed as specified by the manufacturer.

\subsection{Antibodies}

Rat anti-mouse CD3 antibody YCD3-1 [63] was obtained in-house by affinity chromatography from hybridoma supernatants; Syrian hamster anti-mouse CD28 (37.51) was purified from culture supernatants or obtained from BD Biosciences (San Jose, CA, USA). Antibodies coupled to different fluorochromes or biotin were purchased from eBioscience, ImmunoTools GmbH (Friesoythe, Germany), or BioLegend (San Diego, CA, USA), and included rat anti-mouse CD3, CD4, CD8, CD19, CD25, CD44, CD62L, CD185 (CXCR5), CD279 (PD-1), Foxp3 and Eomes; Armenian hamster anti-CD278 (ICOS), and adequate isotype controls.

\subsection{Flow Cytometry}

Single cell suspensions $\left(0.5-1 \times 10^{6}\right)$ from spleen or spleen subpopulations, or from draining lymph nodes of mice undergoing EAE, were incubated in $50 \mu \mathrm{L}$ of $10 \%$ heatinactivated normal mouse serum in staining buffer (PBS, $0.05 \% \mathrm{NaN}_{3}, 5 \%$ heat-inactivated FBS) in the cold. Then, they were incubated with fluorochrome-labelled antibodies in the same buffer for a further $20 \mathrm{~min}$ in the cold. After washing, the stained cells were fixed with $1 \%$ paraformaldehyde in PBS and analyzed by flow cytometry; or fixed and permeabilized for intracellular staining using the Transcription Factor Staining Buffer Set (eBioscience). Staining with anti-Foxp3, anti-Eomes, or control isotype antibody was performed as indicated by the manufacturer. Eventually, flow cytometry data were acquired using a Beckman Coulter FC-500 flow cytometer (Beckman Coulter, Brea, CA, USA), or FACSCanto (BD Biosciences) or FACS LSR Fortessa (BD Biosciences) flow cytometers. Data were analyzed with FlowLogic (Inivai Technologies, Mentone, Australia), or FlowJo (Tree Star, Inc., Ashland, OR, USA, Version 10.0) softwares.

\subsection{Statistics}

Statistical analysis of data with the two-tailed Student's $t$ test, one-way ANOVA, the $\log$ rank (Mandel-Cox) test and the Pearson correlation coefficient, was performed with GraphPad Prism v. 9.0.0. Asterisks indicate significant differences $\left({ }^{*} p<0.05,{ }^{* *} p<0.01\right.$, $* * * p<0.001)$. Scoring of clinical symptoms of EAE was performed in a blinded manner, without knowledge of genotypes.

Supplementary Materials: The following are available online at https:/ / www.mdpi.com/article/10 .3390/ijms22168698/s1, Figure S1-Figure S6.

Author Contributions: Conceptualization, J.M.R. and P.P.; Formal analysis, M.M.-C., L.A.-F., G.O., J.M.R. and P.P.; Funding acquisition, J.M.R., P.P.; Investigation, M.M.-C., L.A.-F., G.O., J.M.R. and P.P.; Methodology, M.M.-C., L.A.-F., G.O., J.M.R. and P.P.; Project administration, J.M.R. and P.P.; Resources, J.M.R., P.P., U.D.; Supervision, J.M.R., P.P., U.D.; Validation, M.M.-C., L.A.-F., G.O., J.M.R. and P.P.; Visualization, J.M.R. and P.P.; Writing—original draft, J.M.R. and P.P.; Writing-review 
and editing, M.M.-C., L.A.-F., G.O., U.D., J.M.R. and P.P. All authors have read and agreed to the published version of the manuscript.

Funding: This research was supported by Grants PI13/01809 (to JMR), PI13/02153 and PI16CIII/00012 (to PP) from "Acción Estratégica en Salud, Plan Estatal I+D+i", Ministerio de Economía, Industria y Competitividad (MINECO, Spain), and by the Associazione Italiana Ricerca sul Cancro (Grant IG20714, AIRC, Milan) and Fondazione Cariplo (2017-0535) (to U.D.).

Institutional Review Board Statement: Experiments were performed in agreement with applicable institutional, national and European Union guidelines and were approved by the Ethics and Animal Welfare Committees of CSIC and the Instituto de Salud Carlos III (OEBA-Majadahonda and CEIYBA). Procedures were carried out under project licenses PROEX 181/15 (to JMR, CSIC) and PROEX 330/15 (to PP, ISCIII) issued by the Consejería de Medio Ambiente y Ordenación del Territorio, Comunidad de Madrid (Spain).

Informed Consent Statement: Not applicable.

Data Availability Statement: The data presented in this study are available on reasonable request from the corresponding authors.

Acknowledgments: The authors thank the staff of the Cytometry and Veterinary Units of the Instituto de Salud Carlos III (Majadahonda, Madrid, Spain) and Centro de Investigaciones Biológicas Margarita Salas, CSIC (Madrid, Spain) for technical assistance.

Conflicts of Interest: The authors declare no conflict of interest.

\section{References}

1. Dendrou, C.A.; Fugger, L.; Friese, M.A. Immunopathology of multiple sclerosis. Nat. Rev. Immunol. 2015, 15, 545-558. [CrossRef]

2. Baecher-Allan, C.; Kaskow, B.J.; Weiner, H.L. Multiple Sclerosis: Mechanisms and immunotherapy. Neuron 2018, 97, 742-768. [CrossRef]

3. Procaccini, C.; De Rosa, V.; Pucino, V.; Formisano, L.; Matarese, G. Animal models of Multiple Sclerosis. Eur. J. Pharmacol. 2015, 759, 182-191. [CrossRef]

4. Wagner, C.A.; Roqué, P.J.; Goverman, J.M. Pathogenic T cell cytokines in multiple sclerosis. J. Exp. Med. 2020, 217, e20190460. [CrossRef]

5. Petermann, F.; Korn, T. Cytokines and effector T cell subsets causing autoimmune CNS disease. FEBS Lett. 2011, 585, 3747-3757. [CrossRef]

6. McGeachy, M.J.; Stephens, L.A.; Anderton, S.M. Natural recovery and protection from Autoimmune Encephalomyelitis: Contribution of $\mathrm{CD}^{+} \mathrm{CD} 25^{+}$regulatory cells within the central nervous system. J. Immunol. 2005, 175, 3025-3032. [CrossRef]

7. Zhang, X.; Reddy, J.; Ochi, H.; Frenkel, D.; Kuchroo, V.K.; Weiner, H.L. Recovery from experimental allergic encephalomyelitis is TGF- $\beta$ dependent and associated with increases in $\mathrm{CD}^{+} \mathrm{LAP}^{+}$and $\mathrm{CD} 4^{+} \mathrm{CD} 25^{+} \mathrm{T}$ cells. Int. Immunol. 2006, 18, 495-503. [CrossRef]

8. Vasileiadis, G.K.; Dardiotis, E.; Mavropoulos, A.; Tsouris, Z.; Tsimourtou, V.; Bogdanos, D.P.; Sakkas, L.I.; Hadjigeorgiou, G.M. Regulatory B and T lymphocytes in multiple sclerosis: Friends or foes? Auto. Immun. Highlights 2018, 9, 9. [CrossRef]

9. Anderson, A.C.; Reddy, J.; Nazareno, R.; Sobel, R.A.; Nicholson, L.B.; Kuchroo, V.K. IL-10 plays an important role in the homeostatic regulation of the autoreactive repertoire in naive mice. J. Immunol. 2004, 173, 828-834. [CrossRef]

10. Greve, B.; Vijayakrishnan, L.; Kubal, A.; Sobel, R.A.; Peterson, L.B.; Wicker, L.S.; Kuchroo, V.K. The diabetes susceptibility locus Idd5.1 on mouse chromosome 1 regulates ICOS expression and modulates murine Experimental Autoimmune Encephalomyelitis. J. Immunol. 2004, 173, 157-163. [CrossRef]

11. Miyamoto, K.; Kingsley, C.I.; Zhang, X.; Jabs, C.; Izikson, L.; Sobel, R.A.; Weiner, H.L.; Kuchroo, V.K.; Sharpe, A.H. The ICOS molecule plays a crucial role in the development of mucosal tolerance. J. Immunol. 2005, 175, 7341-7347. [CrossRef]

12. Fitzgerald, D.C.; Zhang, G.-X.; El-Behi, M.; Fonseca-Kelly, Z.; Li, H.; Yu, S.; Saris, C.J.; Gran, B.; Ciric, B.; Rostami, A. Suppression of autoimmune inflammation of the central nervous system by interleukin 10 secreted by interleukin 27-stimulated T cells. Nat. Immunol. 2007, 8, 1372-1379. [CrossRef] [PubMed]

13. Pot, C.; Jin, H.; Awasthi, A.; Liu, S.M.; Lai, C.-Y.; Madan, R.; Sharpe, A.H.; Karp, C.L.; Miaw, S.-C.; Ho, I.C.; et al. IL-27 induces the transcription factor c-Maf, cytokine IL-21, and the costimulatory receptor ICOS that coordinately act together to promote differentiation of IL-10-producing Tr1 cells. J. Immunol. 2009, 183, 797-801. [CrossRef]

14. Rojo, J.M.; Pini, E.; Ojeda, G.; Bello, R.; Dong, C.; Flavell, R.A.; Dianzani, U.; Portoles, P. CD4 ${ }^{+}$ICOS $^{+}$T lymphocytes inhibit T cell activation 'in vitro' and attenuate autoimmune encephalitis 'in vivo'. Int. Immunol. 2008, 20, 577-589. [CrossRef] [PubMed]

15. Adefemi, F.; Fruman, D.A.; Marshall, A.J. A case for Phosphoinositide 3-Kinase-targeted therapy for infectious disease. J. Immunol. 2020, 205, 3237-3245. [CrossRef] [PubMed]

16. Stark, A.-K.; Sriskantharajah, S.; Hessel, E.M.; Okkenhaug, K. PI3K inhibitors in inflammation, autoimmunity and cancer. Curr. Opin. Pharmacol. 2015, 23, 82-91. [CrossRef] 
17. Banham-Hall, E.; Clatworthy, M.R.; Okkenhaug, K. The therapeutic potential for PI3K inhibitors in autoimmune rheumatic diseases. Open Rheumatol. J. 2012, 6, 245-258. [CrossRef]

18. Vanhaesebroeck, B.; Guillermet-Guibert, J.; Graupera, M.; Bilanges, B. The emerging mechanisms of isoform-specific PI3K signalling. Nat. Rev. Mol. Cell. Biol. 2010, 11, 329-341. [CrossRef]

19. Huang, Y.H.; Sauer, K. Lipid signaling in T-cell development and function. Cold Spring Harb. Perspect. Biol. 2010, 2, a002428. [CrossRef]

20. Fruman, D.A.; Bismuth, G. Fine tuning the immune response with PI3K. Immunol. Rev. 2009, 228, 253-272. [CrossRef]

21. Rommel, C.; Camps, M.; Ji, H. PI3K $\delta$ and PI3K $\gamma$ : Partners in crime in inflammation in rheumatoid arthritis and beyond? Nat. Rev. Immunol. 2007, 7, 191-201. [CrossRef]

22. Deane, J.A.; Fruman, D.A. Phosphoinositide 3-Kinase: Diverse roles in immune cell activation. Annu. Rev. Immunol. 2004, 22, 563-598. [CrossRef]

23. Koyasu, S. The role of PI3K in immune cells. Nat. Immunol. 2003, 4, 313-319. [CrossRef]

24. Okkenhaug, K.; Patton, D.T.; Bilancio, A.; Garcon, F.; Rowan, W.C.; Vanhaesebroeck, B. The p1108 isoform of Phosphoinositide 3-kinase controls clonal expansion and differentiation of Th cells. J. Immunol. 2006, 177, 5122-5128. [CrossRef]

25. Ji, H.; Rintelen, F.; Waltzinger, C.; Bertschy Meier, D.; Bilancio, A.; Pearce, W.; Hirsch, E.; Wymann, M.P.; Ruckle, T.; Camps, M.; et al. Inactivation of PI3K $\gamma$ and PI3K $\delta$ distorts T-cell development and causes multiple organ inflammation. Blood 2007, 110, 2940-2947. [CrossRef]

26. Liu, D.; Zhang, T.; Marshall, A.J.; Okkenhaug, K.; Vanhaesebroeck, B.; Uzonna, J.E. The p1108 isoform of Phosphatidylinositol 3-Kinase controls susceptibility to Leishmania major by regulating expansion and tissue homing of regulatory T cells. J. Immunol. 2009, 183, 1921-1933. [CrossRef]

27. Utsugi, M.; Dobashi, K.; Ono, A.; Ishizuka, T.; Matsuzaki, S.-i.; Hisada, T.; Shimizu, Y.; Kawata, T.; Aoki, H.; Kamide, Y.; et al. PI3K p110 $\beta$ positively regulates Lipopolysaccharide-induced IL-12 production in human macrophages and dendritic cells and JNK1 plays a novel role. J. Immunol. 2009, 182, 5225-5231. [CrossRef]

28. Haylock-Jacobs, S.; Comerford, I.; Bunting, M.; Kara, E.; Townley, S.; Klingler-Hoffmann, M.; Vanhaesebroeck, B.; Puri, K.D.; McColl, S.R. PI3K $\delta$ drives the pathogenesis of experimental autoimmune encephalomyelitis by inhibiting effector T cell apoptosis and promoting Th17 differentiation. J. Autoimmun. 2011, 36, 278-287. [CrossRef]

29. Steinbach, E.C.; Kobayashi, T.; Russo, S.M.; Sheikh, S.Z.; Gipson, G.R.; Kennedy, S.T.; Uno, J.K.; Mishima, Y.; Borst, L.B.; Liu, B.; et al. Innate PI3K p1108 regulates Th1/Th17 development and microbiota-dependent colitis. J. Immunol. 2014, 192, $3958-3968$. [CrossRef]

30. Aragoneses-Fenoll, L.; Montes-Casado, M.; Ojeda, G.; Acosta, Y.Y.; Herranz, J.; Martínez, S.; Blanco-Aparicio, C.; Criado, G.; Pastor, J.; Dianzani, U.; et al. ETP-46321, a dual p110 $\alpha / \delta$ class IA phosphoinositide 3-kinase inhibitor modulates T lymphocyte activation and collagen-induced arthritis. Biochem. Pharmacol. 2016, 106, 56-69. [CrossRef]

31. Aragoneses-Fenoll, L.; Ojeda, G.; Montes-Casado, M.; Acosta-Ampudia, Y.; Dianzani, U.; Portolés, P.; Rojo, J.M. T-cell specific loss of the PI-3 kinase $\mathrm{p} 110 \alpha$ catalytic subunit results in enhanced cytokine production and anti tumor response. Front. Immunol. 2018, 9, e332. [CrossRef]

32. Qiao, S.; Zheng, N.; Sun, L.; Pang, G.; Wang, S.; Jia, P.; Uzonna, J.; Bai, H.; Yang, X. The p1108 Isoform of Phosphatidylinositol 3-Kinase plays an important role in host defense against Chlamydial lung infection through influencing $\mathrm{CD}^{+} \mathrm{T}$ cell function. Pathog. Dis. 2018, 76, fty053. [CrossRef]

33. Yang, C.; Chen, X.; Wei, Z.; Xiao, J.; Chen, W.; Shang, Y.; Liu, J. Targeting the class IA PI3K isoforms p110 $\alpha / \delta$ attenuates heart allograft rejection in mice by suppressing the CD4 ${ }^{+}$T lymphocyte response. Am. J. Transl. Res. 2018, 10, 1387-1399.

34. Patton, D.T.; Garden, O.A.; Pearce, W.P.; Clough, L.E.; Monk, C.R.; Leung, E.; Rowan, W.C.; Sancho, S.; Walker, L.S.K.; Vanhaesebroeck, B.; et al. Cutting edge: The phosphoinositide 3-kinase p1108 is critical for the function of CD $4^{+} \mathrm{CD} 25^{+} \mathrm{Foxp} 3^{+}$ regulatory T cells. J. Immunol. 2006, 177, 6598-6602. [CrossRef]

35. Ali, K.; Soond, D.R.; Pineiro, R.; Hagemann, T.; Pearce, W.; Lim, E.L.; Bouabe, H.; Scudamore, C.L.; Hancox, T.; Maecker, H.; et al. Inactivation of PI(3)K p1108 breaks regulatory T-cell-mediated immune tolerance to cancer. Nature 2014, 510, 407-411. [CrossRef]

36. Lim, E.L.; Cugliandolo, F.M.; Rosner, D.R.; Gyori, D.; Roychoudhuri, R.; Okkenhaug, K. Phosphoinositide 3-kinase $\delta$ inhibition promotes antitumor responses but antagonizes checkpoint inhibitors. JCI Insight 2018, 3, e120626. [CrossRef]

37. Chellappa, S.; Kushekhar, K.; Munthe, L.A.; Tjønnfjord, G.E.; Aandahl, E.M.; Okkenhaug, K.; Taskén, K. The PI3K p1108 isoform inhibitor Idelalisib preferentially inhibits human regulatory T cell function. J. Immunol. 2019, 202, 1397-1405. [CrossRef]

38. David, J.S.; Dominik, A.; Christopher, A.L.; Krishnendu, C.; Jonathan, C.; Sumeet, P.; Karin, R.E.; Rui, C.; Athena, C.; Yuchun, D.; et al. Immunodeficiency, autoimmune thrombocytopenia and enterocolitis caused by autosomal recessive deficiency of PIK3CD-encoded phosphoinositide 3-kinase $\delta$. Haematologica 2019, 104, e483-e486. [CrossRef]

39. Stark, A.-K.; Davenport, E.C.M.; Patton, D.T.; Scudamore, C.L.; Vanhaesebroeck, B.; Veldhoen, M.; Garden, O.A.; Okkenhaug, K. Loss of phosphatidylinositol 3-kinase activity in regulatory T cells leads to neuronal inflammation. J. Immunol. 2020, 205, 78-89. [CrossRef]

40. Hawkins, P.T.; Anderson, K.E.; Davidson, K.; Stephens, L.R. Signalling through Class I PI3Ks in mammalian cells. Biochem. Soc. Transac. 2006, 34, 647-662. [CrossRef] [PubMed]

41. Acosta, Y.; Zafra, M.; Ojeda, G.; Bernardone, I.; Dianzani, U.; Portolés, P.; Rojo, J. Biased binding of class IA phosphatidyl inositol 3-kinase subunits to inducible costimulator (CD278). Cell. Mol. Life Sci. 2011, 68, 3065-3079. [CrossRef] 
42. Graupera, M.; Guillermet-Guibert, J.; Foukas, L.C.; Phng, L.-K.; Cain, R.J.; Salpekar, A.; Pearce, W.; Meek, S.; Millan, J.; Cutillas, P.R.; et al. Angiogenesis selectively requires the p110 $\alpha$ isoform of PI3K to control endothelial cell migration. Nature 2008, 453, 662-666. [CrossRef]

43. Acosta, Y.Y.; Montes-Casado, M.; Aragoneses-Fenoll, L.; Dianzani, U.; Portolés, P.; Rojo, J.M. Suppression of CD4 ${ }^{+}$T lymphocyte activation "in vitro" and experimental encephalomyelitis "in vivo" by the phosphatidyl inositol 3-kinase inhibitor PIK-75. Int. J. Immunopathol. Pharmacol. 2014, 27, 53-67. [CrossRef]

44. Matejuk, A.; Hopke, C.; Vandenbark, A.A.; Hurn, P.D.; Offner, H. Middle-Age male mice have increased severity of Experimental Autoimmune Encephalomyelitis and are unresponsive to testosterone therapy. J. Immunol. 2005, 174, 2387-2395. [CrossRef]

45. Seo, J.-E.; Hasan, M.; Han, J.-S.; Kang, M.-J.; Jung, B.-H.; Kwok, S.-K.; Kim, H.-Y.; Kwon, O.-S. Experimental autoimmune encephalomyelitis and age-related correlations of NADPH oxidase, MMP-9, and cell adhesion molecules: The increased disease severity and blood-brain barrier permeability in middle-aged mice. J. Neuroimmunol. 2015, 287, 43-53. [CrossRef]

46. Peferoen, L.A.N.; Breur, M.; van de Berg, S.; Peferoen-Baert, R.; Boddeke, E.H.W.G.M.; van der Valk, P.; Pryce, G.; van Noort, J.M.; Baker, D.; Amor, S. Ageing and recurrent episodes of neuroinflammation promote progressive experimental autoimmune encephalomyelitis in Biozzi ABH mice. Immunology 2016, 149, 146-156. [CrossRef]

47. Crawford, A.; Angelosanto, J.M.; Kao, C.; Doering, T.A.; Odorizzi, P.M.; Barnett, B.E.; Wherry, E.J. Molecular and transcriptional basis of $\mathrm{CD}^{+} \mathrm{T}$ cell dysfunction during chronic infection. Immunity 2014, 40, 289-302. [CrossRef]

48. Lupar, E.; Brack, M.; Garnier, L.; Laffont, S.; Rauch, K.S.; Schachtrup, K.; Arnold, S.J.; Guéry, J.-C.; Izcue, A. Eomesodermin expression in CD4 ${ }^{+} \mathrm{T}$ cells restricts peripheral Foxp3 induction. J. Immunol. 2015, 195, 4742. [CrossRef]

49. Fu, W.; Liu, X.; Lin, X.; Feng, H.; Sun, L.; Li, S.; Chen, H.; Tang, H.; Lu, L.; Jin, W.; et al. Deficiency in T follicular regulatory cells promotes autoimmunity. J. Exp. Med. 2018, 215, 815-825. [CrossRef]

50. Burmeister, Y.; Lischke, T.; Dahler, A.C.; Mages, H.W.; Lam, K.-P.; Coyle, A.J.; Kroczek, R.A.; Hutloff, A. ICOS controls the pool size of effector-memory and regulatory T cells. J. Immunol. 2008, 180, 774-782. [CrossRef]

51. Ito, T.; Hanabuchi, S.; Wang, Y.-H.; Park, W.R.; Arima, K.; Bover, L.; Qin, F.X.-F.; Gilliet, M.; Liu, Y.-J. Two functional subsets of Foxp ${ }^{+}$regulatory $\mathrm{T}$ cells in human thymus and periphery. Immunity 2008, 28, 870-880. [CrossRef]

52. Channappanavar, R.; Twardy, B.S.; Krishna, P.; Suvas, S. Advancing age leads to predominance of inhibitory receptor expressing CD4 T cells. Mech. Ageing Dev. 2009, 130, 709-712. [CrossRef]

53. Francisco, L.M.; Salinas, V.H.; Brown, K.E.; Vanguri, V.K.; Freeman, G.J.; Kuchroo, V.K.; Sharpe, A.H. PD-L1 regulates the development, maintenance, and function of induced regulatory T cells. J. Exp. Med. 2009, 206, 3015-3029. [CrossRef]

54. Tan, C.L.; Kuchroo, J.R.; Sage, P.T.; Liang, D.; Francisco, L.M.; Buck, J.; Thaker, Y.R.; Zhang, Q.; McArdel, S.L.; Juneja, V.R.; et al. PD-1 restraint of regulatory T cell suppressive activity is critical for immune tolerance. J. Exp. Med. 2021, 218 , e20182232. [CrossRef]

55. Mittelsteadt, K.L.; Hayes, E.T.; Campbell, D.J. ICOS signaling limits regulatory T cell accumulation and function in visceral adipose tissue. J. Exp. Med. 2021, 218, e20201142. [CrossRef]

56. Montes-Casado, M.; Ojeda, G.; Criado, G.; Rojo, J.M.; Portolés, P. The PI-3-kinase p110 $\alpha$ catalytic subunit of T lymphocytes modulates Collagen-Induced Arthritis. Int. J. Mol. Sci. 2021, 22, 6405. [CrossRef]

57. Srinivasan, L.; Sasaki, Y.; Calado, D.P.; Zhang, B.; Paik, J.H.; DePinho, R.A.; Kutok, J.L.; Kearney, J.F.; Otipoby, K.L.; Rajewsky, K. PI3 kinase signals BCR-dependent mature B cell survival. Cell 2009, 139, 573-586. [CrossRef]

58. Ramadani, F.; Bolland, D.J.; Garcon, F.; Emery, J.L.; Vanhaesebroeck, B.; Corcoran, A.E.; Okkenhaug, K. The PI3K isoforms p110 $\alpha$ and p1108 are essential for pre-B cell receptor signaling and B cell development. Sci. Signal. 2010, 3, ra60. [CrossRef] [PubMed]

59. Huber, S.; Gagliani, N.; Esplugues, E.; O'Connor, W.; Huber, F.J.; Chaudhry, A.; Kamanaka, M.; Kobayashi, Y.; Booth, C.J.; Rudensky, A.Y.; et al. Th17 cells express Interleukin-10 receptor and are controlled by Foxp3- and Foxp3 ${ }^{+}$regulatory CD4 ${ }^{+} \mathrm{T}$ cells in an Interleukin-10-dependent manner. Immunity 2011, 34, 554-565. [CrossRef]

60. Chaudhry, A.; Samstein, R.M.; Treuting, P.; Liang, Y.; Pils, M.C.; Heinrich, J.-M.; Jack, R.S.; Wunderlich, F.T.; Brüning, J.C.; Müller, W.; et al. Interleukin-10 signaling in regulatory T cells is required for suppression of Th17 cell-mediated inflammation. Immunity 2011, 34, 566-578. [CrossRef] [PubMed]

61. Lee, P.P.; Fitzpatrick, D.R.; Beard, C.; Jessup, H.K.; Lehar, S.; Makar, K.W.; Pérez-Melgosa, M.; Sweetser, M.T.; Schlissel, M.S.; Nguyen, S.; et al. A critical role for Dnmt1 and DNA methylation in T cell development, function, and survival. Immunity 2001, 15, 763-774. [CrossRef]

62. Suen, W.E.; Bergman, C.M.; Hjelmstrom, P.; Ruddle, N.H. A critical role for Lymphotoxin in Experimental Allergic Encephalomyelitis. J. Exp. Med. 1997, 186, 1233-1240. [CrossRef]

63. Portoles, P.; Rojo, J.; Golby, A.; Bonneville, M.; Gromkowski, S.; Greenbaum, L.; Janeway, C.A., Jr.; Murphy, D.B.; Bottomly, K. Monoclonal antibodies to murine CD3 epsilon define distinct epitopes, one of which may interact with CD4 during T cell activation. J. Immunol. 1989, 142, 4169-4175. 